\title{
Communicative language teaching in reading comprehension
}

Communicative language teaching in reading comprehension

Juan Elías Yucailla Tixi. ${ }^{1}$

Recibido:08-10-2020 / Revisado: 26-10-2020 /Aceptado: 13-11-2020/ Publicado: 05-12-2020

Resumen

DOI: $\underline{\text { https://doi.org/10.33262/concienciadigital.v3i4.1.1486 }}$

Introduction. Comunicative Language teaching (CLT) is generally believed to be used to teach language for communication and interaction purposes. Therefore, it seems to be more suitable in developing speaking skill. The possibility of applying CLT in the development of other skills such as reading comprehension has not been sufficiently explored. Research Aim. The purpose of this literature review is to examine communicative language teaching and its impact on reading comprehension presenting a case for the consideration at Unidad Educativa Liceo Policial Chimborazo. Methodology. Two electronic databases were searched with a limitation of forty years to reflect the most relevant information. Lists of relevant research were also examined. A total of 32 articles were selected for review. Two themes lead the literature review: 'Communicative language teaching', and 'Reading comprehension'. Key Findings. It was found that communicative language teaching gives the teacher the opportunity to design programs to explore other aspects of language like reading. Conclusions. Based on the literature reviewed and its preceding discussion, it is concluded that, even though, communicative language teaching has been criticized for focusing more on the communicative aspect of language learning, this method in Ecuador is likely to bolster most students' academic performance rates and improve the overall reading rate of the country.

\footnotetext{
${ }^{1}$ U.C. Liceo Policial, Riobamba, Ecuador. juan.yucailla@educacion.gob.ec
} https://orcid.org/0000-0001-9006-4005 
Key Words: Communicative language teaching (CLT), reading comprehension, language learning method.

\section{Resumen}

Introducción. Generalmente se cree que la enseñanza comunicativa del lenguaje (ECL) se utiliza para enseñar el lenguaje con fines de comunicación e interacción. Por lo tanto, parece ser más adecuada para desarrollar la habilidad de hablar. No se ha explorado suficientemente la posibilidad de aplicar (ECL) en el desarrollo de otras habilidades como la comprensión lectora. Objetivo. El propósito de esta revisión de bibliográfica es examinar la enseñanza comunicativa de la lengua y su impacto en la comprensión lectora, presentando un caso a consideración en la Unidad Educativa Liceo Policial Chimborazo. Metodología. Se realizaron búsquedas en dos bases de datos electrónicas con una limitación de cuarenta años para reflejar la información más relevante. También se examinaron listas de investigaciones relevantes. Se seleccionaron un total de 32 artículos para su revisión. Dos temas encabezan la revisión de la literatura: "Enseñanza comunicativa de la lengua " y "Comprensión lectora". Resultados. Se encontró que la enseñanza comunicativa de la lengua le da al maestro la oportunidad de diseñar programas para explorar otros aspectos del lenguaje como la lectura. Conclusiones. Con base en la literatura revisada y su discusión anterior, se concluye que, aunque la enseñanza comunicativa de la lengua ha sido criticada por enfocarse más en el aspecto comunicativo del aprendizaje de lenguas, es probable que este método en el Ecuador refuerce las tasas de rendimiento académico de la mayoría de los estudiantes y mejore la tasa de lectura general del país.

Palabras clave: Enseñanza comunicativa de la lengua (ECL), comprensión lectora, método de aprendizaje de lenguas.

\section{Introduction.}

Communicative language teaching is a communicative approach to the teaching of language that emphasizes interaction (Lee \& VanPatten, 1995). The ultimate goal of interaction driven is to enable the learner to interact effectively. Reading is integral to the academic journey of a student. The ability to read and comprehend text determines the achievements a student can realize in every subject. Reading skills need to be developed through practical approaches and strategies. Teaching reading comprehension affects learners' ability to get a perfect understanding of the text they interact within academia (Richards, 2005). An education system with low academic performance levels could be facing the challenge of poor reading comprehension skills. The research work that the paper embarks on seeks to analyze communicative language teaching and its impact on reading comprehension at Unidad 
Educativa Liceo Policial Chimborazo. Therefore, the paper presents a strong case for the consideration of communicative language teaching in reading comprehension.

\section{Methodology}

A search of the literature was conducted to gather research surrounding the chosen topic. Two electronic databases were utilized, which included Google Scholar and Proquest. Filtering the research question before beginning the literature search was important to ensure findings were accurate, precise and relevant (Jaffe \& Cowell 2014). Search strings were created from the research question following preliminary trial-and-error searches. These search strings were combined using the Boolean operators 'AND' or 'OR', and consisted of "communicative language teaching" (or "communicative approach" or "reading comprehension", (or "reading skill" or "reading ability"). To reflect the highest level of general development of the paper, it was considered to incorporate literature reflecting the development of communicative language teaching, from as early as 1981, up to more recent times. Various websites were also accessed to ensure all relevant literature was found. Reference lists of relevant literature and literature reviews were screened to ensure all noteworthy literature was included in the review.

Results from the literature search yielded 318 articles. After reviewing the titles, 98 articles appeared relevant. The abstracts of these articles were reviewed and 43 articles were found to be relevant to the literature review. A more detailed review of these resulted in 11 articles being discarded. Of the remaining 32 articles, 10 were set in communicative language teaching and 22 were set in reading comprehension. Studies emanated from around the world were research studies and literature review.

The review of the literature identified two leading themes: Communicative language teaching, and reading comprehension.

\section{Key Findings}

To get an effective communication, one needs to have the ability to read and comprehend text. The concentration on language use through interaction and use of the different skills within the environment results in students' improved ability to communicate effectively using a particular language.

The use of communicative language teaching is not a straitjacket, it occurs in a nonmethodological system by which predetermined programs and materials are established for students. It gives the teacher freedom to design programs for every lesson; emphasizing on how best the learners will acquire the skills necessary to explore other aspects of language like reading. 


\section{Communicative Language Teaching}

Learning institutions that have embraced communicative language teaching have in place mechanisms that allow students learn the language in question through interaction among themselves (Spada, 2007), as well as with their language teachers in the context of interrogating text written in the language they are studying (Spada, 2007). Additionally, communicative language teaching is evidenced in the nature of interaction between students and teachers outside the classroom setting, concerning the students' language (Littlewood \& William, 1981). The critical factor in communicative language teaching is the interaction between instructors and students (Littlewood \& William, 1981) and the interaction among learners in the context of language learning.

Communicative language enables learners to freely share experiences about various aspects of their lives with fellow learners in the context of language learning, making learning more exciting and engaging for them (Savignon, 1987). Instructors embrace communicative language teaching and offer guidance to students outside the realms of the grammatical demands of a language, outlining a broader approach towards the learning of language. The eventual effect is that learners can gain critical language skills applicable to all situations (Savignon, 1987). It becomes easy to appreciate aspects of writing in a language that does not strictly adhere to grammatical rules, such as poetry.

Interaction among learners is an aspect of communicative language teaching. Instructors encourage learners to engage in interactive sessions with each other as much as possible (Savignon, 1991). Learners get to share their personal experiences in the context of language learning and the learning environment. Then the student's effect is that their studies will not solely focus on their ability to learn the instructed language, but also to make their learning experience a worthwhile contribution towards their overall academic journey (Savignon, 1991). Therefore, it is more probable that the overall ability to perform in all other instruction areas is improved thanks to communicative language teaching.

The primary objective of learning a specific language is to conformably and effectively communicate in the language of instruction. Other forms of language learners tend to focus more on grammatical competence (Nunan, 1987). Therefore, teachers play the strict role of instructors. Additionally, the assessment of learners concentrates on the mastering of grammatical rules and demands of language. A student can easily pass a test in a language but still be a poor communicator when the same language is used as a communication tool. Communicative language teaching appears to concentrate more on the contrary (Liao, 2004). The ability to effectively communicate in the language of instruction is primary to any other language teaching objective and learning. The role played by the teacher significantly differs from other forms of language learning, with the teacher being more of a facilitator than an instructor. The teacher guides the students towards the mastery of language, facilitating interaction within the learning environment. 
Communicative language learning occurs in a non-methodological system whereby predetermined programs and materials are set for learners (Thompson, 1996). On the contrary, the focus is on learners' oral and verbal skills before they are introduced to reading and writing in a language (Thompson, 1996). Based on the students' circumstances and the nature of their learning environment, the teacher is free to design programs for every lesson; on how best the learners will acquire the skills necessary to explore other aspects of language use.

\section{Reading Comprehension}

Reading comprehension refers to one's ability to process written text, get meaning out of it, and relate such text with the knowledge already inherent in the reader. A student with high reading comprehension prowess reflects several fundamental skills (Hiep, 2007). First, such students know the meaning of words found in the text and understand it based on the writing context. Secondly, students with good reading comprehension skills can easily follow through the organization of a passage and point out references and antecedents across the passage (Hiep, 2007), draw inferences, point out thought emanating from the passage, and answer any questions posed from the passage read.

More complex reading comprehension skills are reflected in the learner's ability to appreciate the use of literary devices in written text and the situational mood of text (Sato \& Kleinsasser, 999). Such skills enable the learner to get more out of the text, including tone of writing, reference points, assertions, and inflections.

The most significant aspect of reading comprehension is the reader's ability to interrogate text and establish its purpose for writing such text (Belchamber, 2007). A student who can point out the intention that the writer had while coming up with a piece of text and gauge the writer's point of view on a matter has demonstrated high levels of communication comprehension skills (Belchamber, 2007). Additionally, the ability to draw inferences about the author is reflective of high reading comprehension skills.

\section{Communicative Language Teaching in Reading Comprehension}

Communicative language teaching has gained worldwide acclamation concerning its effectiveness in language learning and critical language skills (Galloway, 1993). The paper aims to contribute to the improvement of reading comprehension rates in Ecuador. With communicative language teaching being recognized and appreciated as a significant contributor towards effective language learning (Galloway, 1993), constructive criticism of the approach is necessary to establish whether it can effectively impart reading comprehension skills in students.

Communicative language learning is appreciated for its practical approach towards language learning. Interaction between learners and teachers and learners and fellow learners is highly 
encouraged (Revell, \& Flavell, 1979). Teachers of language within communicative languagebased curricula have a practical understanding of language learning and approach it in the same manner. However, linguists have developed many theories on language learning and how students are likely to acquire relevant language skills (Revell, \& Flavell, 1979). The theoretical understanding of language learning differs significantly from the practical understanding of language that teachers in communicative language teaching have. Among the weaknesses that such theories point out in communicative language teaching is the approach assumes knowledge that is non-language specific (Sreehari, 2012), which could impact the learner's ability to gain practice reading comprehension skills.

The theoretical criticisms of communicative language teaching are inaccurate. In as much as the method focus on the practical understanding of the language, it does not prevent the mastery of knowledge that is language non-specific (Jacobs \& Farrell, 2003). As pointed out earlier in the discussion of communicative language teaching, the approach towards language teaching does not have a fixed system of instruction with defined material; students are guided by way of interaction; allowing them to explore various aspect of language in their learning environment (Jacobs \& Farrell, 2003). The ability to make educated guesses increases with heightened interactions between learners and teachers in the context of language learning (Dörnyei, 2009). Reading comprehension among students will improve drastically in such circumstances, making communicative language teaching remains the most effective approach towards developing reading comprehension skills.

The function of language comes as the number one concern of communicative language teaching. The primary purpose of any language is communication. Communication is effected through written text or speech (Wu, 2008). To communicate effectively, one needs to have the ability to read and comprehend text. Communication cannot be complete unless one deciphers the message passed across in whatever form $(\mathrm{Wu}, 2008)$. The concentration on language use through interaction within the environment results in students' improved ability to communicate effectively using a particular language; therefore, communicative language teaching is the most effective tool for language teaching.

The focus on the use of language in communication has been criticized due to the ease with which formal gaps in language learning can be left out, such as the integral aspect of grammar of a specific language that students use quite often in their communication. The criticism assumes that teachers ignore aspects of grammar in their teaching practices whenever they adopt communicative language teaching (Holliday, 1997). The assumption is entirely inaccurate. Even though the focus does not tend to focus on the intricate aspects of drama, the interaction with teachers and learners present the opportunity for the guidance of students in their studies, with the teachers aware of formal aspects of a language, and therefore integrating them as part of the interaction that occurs in the context of learning (Holliday, 1997). Therefore, it is not to assume that a practical approach to language learning that 
focuses on such language's function ignores the structural aspects of a language. Understanding the function of a language and using such language in any context is vital towards being able to read the text and deduce meaning and relate such meaning to the pool of knowledge already at an individual's disposal.

Communicative language teaching is appreciated for its focus on the realization of communicative competence among learners. They encourage interaction among students and between students and teachers set the stage for communication in a language and subsequent perfection of communication skills in a specific language (Woods \& Çakır, 2011). Communicative competence and reading comprehension are directly related. Being able to communicate competently indicates high abilities concerning reading, understanding, and relating to the text. Proficiency in communication has been criticized for not being a direct reflection of mastery and understanding of a language (Al-Arishi, 1991). Such criticism tends to ignore the purpose of language, with the language being preferred as a communication tool over any other secondary purpose or objective. Communication language teaching is, therefore, the best approach towards improving reading comprehension skills among learners.

The discussion on communicative language teaching highlighted the lack of defined structures for teaching language and requirements for teachers in the model of language teaching. There are no prescribed syllabus versions for communicative language teaching; or guides for both students and teachers to be used in the context of such learning engagements (Holliday, 1997). On the contrary, teachers are given the leeway as facilitators to create an environment where learners will engage teachers and their fellow students in the learning of language. An integral part of language has been seemingly ignored by this aspect of communicative language teaching, grammar. Grammatical rules are different between languages and require well-defined structures and requirements and syllabus to teach effectively (Jacobs \& Farrell, 2003). Communicative language teaching is criticized for possibly leading students away from an integral part of the language; grammar. Teachers are viewed as allowing any form of communication in the context of instruction, as long as there is the ability to derive meaning in such communication.

Written communication tends to adhere to the rules of grammar. Reading comprehension relates to the reader's ability to understand what is written, make meaning out of it, and relate it to the world around them. Communicative language teaching seems to aid different aspects of reading comprehension (Dörnyei, 2009). The ability to communicate helps in understanding the meaning of words that one comes across. It is, therefore, easy to read and understand what a written text talks about. The ability to get meaning and relate the text to one's circumstances is boosted further by the interactive nature of communicative language teaching (Dörnyei, 2009). As learners interact with each other, they get to appreciate their circumstances and other people's circumstances. Therefore, relating any piece of information 
they come across to contemporary living becomes easy, which is an essential aspect of reading comprehension.

\section{Conclusions}

- Reading comprehension is essential to the overall success a student registers in academia.

- A learner's success is hinged on their overall academic performance, heavily affected by the ability to read and understand written communication. The use of communicative language teaching in Ecuador is likely to bolster most students' academic performance rates and improve the overall reading rate of the country, which is currently one of the lowest in Latin America.

- Even though communicative language teaching has been criticized for focusing more on the communicative aspect of language learning while ignoring other aspects of language such as structure, it aids in achieving the primary objective of language use, which is communication. Additionally, it is not accurate to state that communicative language teaching ignores various aspects of language, such as grammar.

- Language teachers are professionals, trained professionally by professionals such as linguists. In as much as they adopt an interactive approach towards instruction in language teaching, other aspects of language are still accorded significance due. Reading comprehension will drastically improve with the incorporation of communicative language teaching.

\section{Bibliographic References}

Belchamber, R. (2007). The advantages of communicative language teaching. The internet TESL journal, 13(2), 122-149.

Dörnyei, Z. (2009). The 2010s Communicative language teaching in the 21st century: The 'principled communicative approach'. Perspectives, 36(2), 33-43.

Galloway, A. (1993). Communicative Language Teaching: An Introduction and Sample Activities. ERIC Digest.

Hiep, P. H. (2007). Communicative language teaching: Unity within diversity. ELT journal, 61(3), 193-201.

Holliday, A. (1997). Six lessons: Cultural continuity in communicative language teaching. Language Teaching Research, 1(3), 212-238.

Jacobs, G. M., \& Farrell, T. S. (2003). Understanding and implementtng the CLT (Communicative Language Teaching) paradigm. RELC journal, 34(1), 5-30.

Jaffe R. \& Cowell J.M. (2014) Approaches for improving literature review methods. The Journal of School Nursing 30(4), 236-239. 
Lee, J. F., \& VanPatten, B. (1995). Making Communicative Language Teaching Happen. Volume 1: Directions for Language Learning and Teaching. McGraw-Hill, Inc., 860 Taylor Station Rd., Blacklick, OH 43004-0545; toll-free: 800-722-4726.

Liao, X. (2004). The need for communicative language teaching in China. ELT journal, 58(3), 270-273.

Littlewood, W., \& William, L. (1981). Communicative language teaching: An introduction. Cambridge university press.

Nunan, D. (1987). Communicative language teaching: Making it work. ELT journal, 4l(2), 136-145.

Revell, J., \& Flavell, R. H. (1979). Teaching techniques for communicative English. Macmillan.

Richards, J. C. (2005). Communicative language teaching today (pp. 22-26). Singapore: SEAMEO Regional Language Centre.

Sato, K., \& Kleinsasser, R. C. (1999). Communicative language teaching (CLT): Practical understandings. The Modern Language Journal, 83(4), 494-517.

Savignon, S. J. (1987). Communicative language teaching. Theory into practice, 26(4), 235242.

Savignon, S. J. (1991). Communicative language teaching: State of the art. TESOL quarterly, 25(2), 261-278.

Spada, N. (2007). Communicative language teaching. In International handbook of English language teaching (pp. 271-288). Springer, Boston, MA.

Sreehari, P. (2012). Communicative Language Teaching: Possibilities and Problems. English Language Teaching, 5(12), 87-93.

Thompson, G. (1996). Some misconceptions about communicative language teaching. ELT journal, 50(1), 9-15.

Woods, D., \& Çakır, H. (2011). Two dimensions of teacher knowledge: The case of communicative language teaching. System, 39(3), 381-390.

Wu, W. (2008). Misunderstandings of Communicative Language Teaching. English language teaching, 1(1), 50-53.

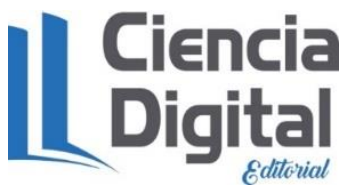




\section{PARA CITAR EL ARTÍCULO INDEXADO.}

Yucailla Tixi, J. E. (2020). Communicative language teaching in reading comprehension. ConcienciaDigital, 3(4.1), 116-125. https://doi.org/10.33262/concienciadigital.v3i4.1.1486

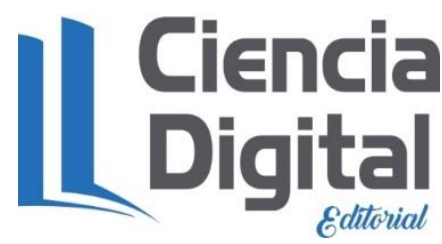

El artículo que se publica es de exclusiva responsabilidad de los autores y no necesariamente reflejan el pensamiento de la Revista Conciencia Digital.

El artículo queda en propiedad de la revista y, por tanto, su publicación parcial y/o total en otro medio tiene que ser autorizado por el director de la Revista Conciencia Digital.

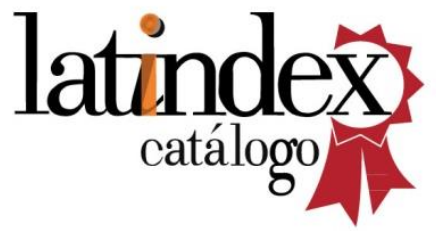

\section{Conciencia}

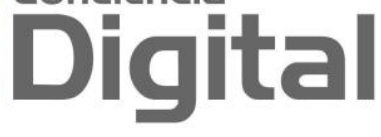

